\title{
Review: An English Suess
}

\section{Author(s): J. S. F.}

Review by: J. S. F.

Source: The Geographical Journal, Vol. 25, No. 6 (Jun., 1905), pp. 666-667

Published by: geographicalj

Stable URL: http://www.jstor.org/stable/1776458

Accessed: 27-06-2016 04:40 UTC

Your use of the JSTOR archive indicates your acceptance of the Terms \& Conditions of Use, available at

http://about.jstor.org/terms

JSTOR is a not-for-profit service that helps scholars, researchers, and students discover, use, and build upon a wide range of content in a trusted digital archive. We use information technology and tools to increase productivity and facilitate new forms of scholarship. For more information about JSTOR, please contact support@jstor.org.

The Royal Geographical Society (with the Institute of British Geographers), Wiley are collaborating with JSTOR to digitize, preserve and extend access to The Geographical Journal 
sea. Usually not more than a few yards in widtb, and rising often only a foot or two above mean tide-level, they run often for several miles from headland tu headland or across the bays. They consist of quartzose sand cemented by carbonate of lime, and have many points in common with the sand-spits and off-shore beaches seen on many exposed coasts. The best known is that which guards the barbour of Pernambuco, but excellent figures and charts of nearly all the best instances are given in this volume.

Coral reefs, also, are known in these seas, but have no close connection with the "stone reefs." Many problems arise regarding their origin and the manner in which their materials have been cemented together so that they can resist the direct attacks of the Atlantic surf. The author points out that the cementing action is confined to those regions where sea-water has nearly its maximum concentration. He believes that river waters, rich in dissolved lime-salts, percolating outwards through the porous sand-reefs, deposit carbonate of lime where they come in contact with the highly saline ocean-water. Prof. Branner's monograph is distinguished for the fulness of detail with which the subject is treated, and the caution with which inferences are made. Incidentally, it contains much interesting information regarding the Tertiary and recent deposits of the Brazilian coast and the changes of level there since Pliocene time.

J. S. F.

\section{MATHEMATICAL AND PHYSICAL GEOGRAPHY.}

\section{An Exglish Suess.}

'The Face of the Earth.' By Edward Suess. Translated by Hertha B. C. Sollas, under the direction of Prof. W. J. Sollas, F.R.s. Vol. 1. Pp. xii., 604. The Clarendon Press. 1904.

Twenty years have now elapsed since the appearance of the first volume of Prof. Suess's 'Antlitz der Erde; and the publication of an English translation witbin the last few months is at least a tribute $t$ ) the originality of the author's conceptions and to the place which the book bolds in geological literature. Most treatises on yeneral scientific subjects are relegated to a back shelf long before they have reached this age. Although the delay in bringing out the book in an English version might seem to imply otherwise, it has always been warmly appreciated in Britain, and its authur has been the recipient of many of the highest honours which English science can award bim. Scattered tbrough the literature of British geology and geography, innumerable references to the 'Antlitz der Erde' will be found, which show how deeply it has made its mark on current speculation regarding all the greater prublems of dynamical geology and geographical evolution. At the universities Prof. Sucss's work has always been much studied, and the British student is now to be congratulated on having so eminently satisfactory a translation at bis hand. Apart altogether from the inherent difficulties of the subject, and the prodigious learning exhibited on every page, the book was by no means easy to read in the original, on account of the graphic and idiomatic German in which it was written. Fe $w$ foreign writers in geological subjects bave the profound and extensive knowledge of the literature of the geology of Britain and British possessions wh:ch Prof. Suess commands, and hence, in its new form, the book will certainly appeal to many geographers, traveliers, and general readers who might not otherwise have been able to familiarize themselves with it.

The translation is a very successful one; clear, terse, and graphic, it bas many of the literary merits of the criginal, aud the occasional bursts of elcquence in which the author indulges have been rendered with considerable skill. The version 
follows the original German edition, and while the orthography ( $f$ some of the geographical names has been modified in accordance with English usage, a few of the wcodcuts retain the German titles. In the French edition many additional jllustrations were introduc $\epsilon$, together with supplementary references to origin 1 sources of information; these make this version on the whole the most useful for geologists, but the task of adequately illustrating the 'Antlitz der Erde' is nearly a hopeless one. In some of the chapters the reader wanders through a maze of geographical names, and to follow all the descriptions in detail would involve the consultation of a library of atlases and papers. Then in a brief and vivid summary the results of the inquiry are brought to a focus, and the great principles involved stand forward in the clearest light.

In this volume we have a syntbetic study of the mo'ntains of the glohe. The work begins with a general introduction in which the main lines of gecl gical evidence are sketched-eartbquakes, volcanoes, changes of level, faulting, and erosion; this includes a brilliant chapter on the Noachian deluge, which, it is argued, finds a rational explanation in a fortuitous conjunction of seismic and cyclonic disturbances over the plains of the lower Euphrates. The second part opens with a discussion of the Alps and the relation batween the great system of Alpine folds and the stable platform of older rocks which lies to the north of them. 'This mountain system is then traced through the great hook-shaped curve of the Apennines into North Africa, and across the pillars of Hercules into the Betic Curdillera, while to the eastward it sweeps through the great semicircle of the Carpathians. The great sunken areas of the Adriatic and the Western Mediterranean are shown to lie within the mountain arcs, and the Tertiary history of the Mediterrancan area is outlined in a brief bat highly significant chapter. From Europe we proceed to Asix, and examine the great mountains which diverge from the upper valley of the Indus. The whole vast system of Tertiary folds is contrasted with the stable areas which lie to the north in Europe, Sibrria, and China, and to the south in Central Africa and the Indian peninsula. Lastly, in two chapters, the mountains of the western hemisphere are briefly discussed.

Over this wide field the author ranges with consummate ease; his knowledge of the geological literature of the most distant countries is equalled by the skill with which he seizes on those facts which are of prime importance. It is his aim to show the harmony which underlies phenomena apparently discordant, and to point out the analogies in structure and history in the different mountain ranges of the world. Criticism may easily be directed on individual points, but the wide sc sp a and philosophic depth of the main argument must impress every reader. Nu boo' has ever proved more stimulating in the best sense than the 'Face of the Earth,' and we return to it again and artin with renewed enjoyment. It is to be hoped that the second volume will appear in English without great delay; the third volume has not yet been completel in the original edition.

\section{J. S. F.}

\section{GENERAL.}

\section{The Position of Geography in Science and Education.}

'Die Erdkunde: eine Darstellung ihrer Wissensgebiete, ihrer Hilfawissenschaften und der Methode ihres Unterrichtes.' Herausgegeben von Maximilian Klar. Leipzig und Wien : 1903-1905.

The necessity of placing the teaching of geography in intermediate education on a higher level than it stands now, is being very keenly felt in Germany and Austria. In proportion as the university teaching of everything connected with the study of our planct and its inhabitants attains an increasingly higher level in 